\title{
AKTIVITAS PENGELOLAAN LAYANAN PUBLIK BERBASIS WEBSITE DI DINAS KOMUNIKASI DAN INFORMATIKA BANYUMAS
}

\author{
Mirra Saefunnissa \\ Institut Agama Islam Negeri (IAIN) Purwokerto \\ E-mail: mirasaefunnisa@gmail.com
}

\begin{abstract}
Abstrak
Penelitian ini atas dasar latar belakang karena banyaknya persoalan aktivitas pemerintah yang disorot masyarakat terkait dengan pelayanan publik. Salah satu aspek layanan yang ingin ditinjau adalah aktifitas pelayanan di instansi Pemerintah Dinas Komunikasi dan Informatika Kabupaten Banyumas yang erat aktivitasnya dengan bidang komunikasi dan informatika yang meliputi telekomunikasi, sarana komunikasi dan diseminasi informasi, telematika, serta pengolahan data elektronik. Dari aspek tersebut perlu sekiranya di analisis bagaimana permasalahan atau kendala yang dialami lembaga publik yang notabenya sebagai penyedia informasi dengan tuntutan kerja menyiapkan segala data yang nantinya akan dipublikasikan. Kemudian tujuan dari penelitian ini yaitu untuk mengetahui bagaimana segala aktivitas pengelolaan informasi layanan publik dalam mewujudkan suatu kualitas komunikasi di Dinas Komunikasi dan Informatika Kabupaten Banyumas. Tujuan dari penelitian ini diantaranya ialah mengetahui bagaimana pelayanan publik yang mana ini merupakan suatu cara Dinas Komunikasi dan Informatika dalam memberikan pelayanan yang transparan, akurat, adil pada publik, dengan demikian badan publik dapat menghasilkan suatu layanan yang berkualitas. Selanjutnya, dari pendokumentasian informasi yang mana ini merupakan suatu kegiatan pencatatan serta penyimpanan informasi yang telah diperoleh dalam satuan kerja dengan melakukan otentikasi dalam informasi, serta pemberian kode pada informasi yang kaitannya dengan pengemasan suatu informasi.
\end{abstract}

Kata Kunci: Aktivitas Layanan Publik; Pengelolaan Informasi; Diskominfo Banyumas.

\section{Abstract}

This research is motivated by the many problems of government activities that are currently increasingly being highlighted by the community, especially those related to public services organized by the Government agencies of the Communication and Informatics Office of Banyumas Regency. One problem is that public institutions, which in fact act as information providers, are led to work continuously by preparing a database of information for publication. Thus the purpose of this study is to determine the activities of public service information management in realizing the quality of communication in the Communication and Informatics Office of Banyumas Regency. The purpose of this research is to find out how public 
servants are a way for the Communication and Information Technology Office to provide transparent, accurate, fair services to the public, so that public agencies can produce quality services. Furthermore, documenting information, which is an activity of recording and storing all information that has been obtained in the work unit by authenticating information, coding the information and its relation to the packaging of information.

Keywords: Public Service Activities; Information Management; Dinkominfo Banyumas.

\section{PENDAHULUAN}

Dinas Komunikasi dan Informatika merupakan suatu lembaga informasi yang mempunyai tugas penting dalam melaksanakan kewenangan daerah. Khususnya di bidang pengelolaan Teknologi Informasi dan Komunikasi serta pelaksanaan tugasnya yang turut dibantu oleh Pemerintah baik dari Pemerintah Provinsi maupun daerah, dengan ruang lingkup kegiatannya erat terkait dengan berbagai Pembangunan serta Pengembangan Sistem Informasi, Pengembangan dan Pemeliharaan Jaringan Komputer Antar Bidang, selanjutnya Pengelolaan Produksi Informasi dan Publikasi, serta Pengelolaan dan Pengembangan Komunikasi Publik. ${ }^{1}$ Sebagai Lembaga informasi pemerintah yang mempunyai tanggung jawab besar dan bergerak di dalam lingkungan Pemerintah, baik dari pusat hingga ke daerah. Termasuk juga aktifitas DINKOMINFO Kabupaten Banyumas mempunyai tugas pokok dan fungsi yang besar dalam membangun Teknologi Informasi dan Komunikasi (TIK) di Kabupaten Banyumas.

Pemerintah Dinas Komunikasi dan Informasi mempunyai beberapa tugas dalam melaksanakan urusan pemerintah daerah atau kewenangan provinsi di bidang teknis aplikasi telematika, pendapatan umum, yang ada hubungan kelembagaannya, sarana komunikasi, destiminasi, pos, telekomunikasi, data informasi dan bina media masa serta tugas pembantuan. ${ }^{2}$ Berdasarkan informasi awal yang diperoleh dari salah satu instansi Kabupaten Banyumas bahwasannya Diskominfo dan pelayanan publik merupakan bagian dari Informasi Pelayanan Publik, PPID, yang sudah memenuhi standarisasi pelayanan informasi publik dengan diberlakukannya

1 Winarno Sugeng dan Indah Septieem Mery, Analisis Jaringan Komputer Dinas Komunikasi dan Informatika, dalam Jurnal Informatika Vol. 3, Januari-April 2012, hal 2.

2 ePPID. https://eppid.kominfo.go.id/. Diakses Sabtu, 6 Maret 2021 pukul 12:35. 
peraturan pemerintah Standar teknis layanan informasi publik di lingkungan Pemerintah Provinsi Jawa Tengah diatur dan ditetapkan berdasarkan Peraturan Gubernur Nomor 47 Tahun 2012 yang direvisi dengan Peraturan Gubernur Nomor 12 Tahun 2015 tentang Petunjuk Pelaksanaan Peraturan Daerah Provinsi Jawa Tengah Nomor 6 Tahun 2012 tentang Pelayanan Informasi Publik Penyelenggaraan Pemerintah Provinsi Jawa Tengah. ${ }^{3}$

Berdasarkan penjabaran aturan pemerintah, atas peran pokok yang dibebankan kepada DINKOMINFO, ada beberapa bidang tugas yang diamanahkan. Salah satu bidang yaitu pengelolaan data layanan publik. Dalam bidang pengelolaan data layanan publik ini, Dinkominfo bertanggung jawab atas seluruh informasi. Baik informasi yang masuk ataupun keluar selaku data pada publik. Seperti telah dipahami data menjadi sumber energi utama dan jadi kebutuhan di dalam sesuatu intansi pemerintahan. Dinkominfo bertanggung jawab atas pengolahan informasi buat dijadikan data yang berguna untuk mendukung kenaikan mutu kehidupan warga Banyumas. Salah satu tugas Dinas Komunikasi serta Informatika (Dinkominfo) Kabupaten Banyumas yaitu mengumpulkan, mencerna, menyebarkan, serta menaruh seluruh data supaya sewaktu-waktu bisa dimanfaatkan buat kepentingan publik, dirujuk menjadi pedoman. Kemudian data publik menjadi sesuatu perihal yang pada dasarnya wajib senantiasa dilindungi, serta jadi hak publik buat mengenali data yang diperuntukan kepada publik. Pertumbuhan teknologi data yang terus menjadi pesat yang menjadikan kebutuhan manusia terhadap data, warga sangat membutuhkan data di masa globalisasi semacam saat ini ini. Semacam yang kita tahu dikala ini sumber data relatif banyak serta tersebar dalam bermacam wujud media penyajiannya, baik lewat media cetak (novel, pesan berita, majalah, bulletin) ataupun media elektronik (radio, tv, hp, internet) bisa dengan gampang diperoleh.

Tetapi dalam pelayanan publik warga senantiasa berharap buat memperoleh data yang bermutu dan memuaskan. Dalam permasalahan ini lembaga publik selaku penyedia data publik dituntut buat bekerja dalam mempersiapkan database data publik yang bersangkutan. Kenaikan mutu pelayanan publik yang diselenggarakan

3 PPID Kabupaten Banyumas. Profil Singkat PPID. Online at http://ppid.banyumaskab.go.id/page/21788/profil-singkat-ppid. Di akses pada tanggal 6 Maret 2021 Pukul 13:05. 
lembaga pemerintah saat ini terus menjadi mengemuka apalagi jadi tuntutan warga ataupun para penerima layanan yakni mutu yang menempel pada segala aspek pelayanan.

Salah satu bagian dari aktivitas pemerintahan yang saat ini fokus disorot oleh warga yakni pelayanan publik yang diselenggarakan oleh lembaga pemerintah. Kenaikan mutu pelayanan publik yang diselenggarakan lembaga pemerintah saat ini terus menjadi mengemuka apalagi bisa jadi tuntutan warga ataupun para penerima layanan, ialah mutu yang menempel pada segala aspek pelayanan. Arah yang mau dicapai dalam pengelolaan data yang bermutu, gampang, kilat serta bayaran ringan kinerja tubuh publik transparan, efisien, efektif serta akuntabel. Ada pula kasus pada riset ini merupakan warga kurang mengenali guna yang dilaksanakan oleh Dinas Komunikasi serta Informatika Kabupaten Banyumas. Disebabkan sebagian warga kurang pembaharuan serta tidak telalu menjajaki data yang diterbitkan oleh Dinkominfo. Terpaut dengan kasus yang sudah dijabarkan diatas, hingga perlunya diadakan sesuatu riset dengan judul: "Aktivitas Pengelolaan Informasi Layanan Publik dalam Mewujudkan Kualitas Pelayanan Informasi Publik di Dinas Komunikasi dan Informatika Kabupaten Banyumas”.

\section{METODE}

Penelitian ini merupakan penelitian deskriptif, yang mana penelitian desktiptif ini berusaha untuk menuturkan suatu pemecahan masalah yang ada sekarang berdasarkan data, juga menyajikan data, menganalisis serta menginterpretasi. Disebut penelitian deskriptif melainkan pada penelitian ini hanya untuk mendeskripsikan suatu keadaan objek penelitian, yaitu menjelaskan program aktivitas pengelola layanan publik yang berbasis website di Dinkominfo Kab. Banyumas.

Pendekatan yang digunakan dalam penelitian ini ialah pendekatan kualitatif. Menurut Lexy J. Moleong, merupakan penelitian kualitatif yang menggunakan metode kualitatif yaitu pengamatan, wawancara, atau telaah dokumen. Metode kualitatif juga dapat dijadikan sebagai prosedur penelitian yang menghasilkan suatu data deskriptif yang berupa kata tertulis atau lisan dari orang-orang serta perilaku 
yang dapat diamati. Dengan demikian data yang sudah terkumpul ialah data yang berupa kata-kata, gambar, dan bukan dari data angka. ${ }^{4}$

Berdasarkan dari jenis dan metode penelitian diatas maka penelitian ini sebagai prosedur untuk mengetahui bagaimana upaya pemerintah daerah Kabupaten Banyumas dalam aktivitas pengelola layanan publik di Dinas Komunikasi dan Infotmatika Kabupaten Banyumas. Pelaksanaan Praktik Pengalaman Lapangan (PPL), dimulai sejak 26 Januari 2021. Secara garis besar, kegiatan PPL ini terdiri atas:

1. Tahap Persiapan

Tahap persiapan diawali dengan kegiatan sebagai berikut:

a. Pembekalan

1). Pelaksanaan pembekalan dilaksanakan secara serentak dengan menggunakan aplikasi zoom meeting.

2). Setiap mahasiswa calon peserta PPL diwajibkan mengikuti kegiatan pembekalan PPL.

3). Pelaksanaan pembekalan dipandu oleh tim panitia PPL yang diketuai oleh Nur Azizah, M.Si.

b. Observasi di Dinas Komunikasi dan Informatika

Kegiatan observasi dilakukan untuk memperoleh gambaran nyata tentang pelaksanaan Layanan Informasi Publik dan kondisi di Dinkominfo secara umum. Observasi perangkat layanan meliputi Website, Publikasi, Tinjauan langsung terkait pelayanan informasi itu sendiri. Sarana kegiatan seperti ruang dinas yang memadai, computer, print out, Meghaphone Speaker (alat pengeras suara), dan lain-lain. Observasi keadaan fisik dinkominfo meliputi sarana prasaranan kantor dinas, kegiatan di lokasi, dan lain-lain. Hasil observasi nantinya akan digunakan untuk menyusun program PPL.

c. Praktik Kegiatan

1). Mahasiswa meminta bahan dari guru pamong tentang data atau materi yangnantinya akan di praktikan.

\footnotetext{
${ }^{4}$ Lexy J. Moleong. Metode Penelitian Kualitatif. (Bandung: Remaja Rosdakarya, 2009), $10-11$.
} 
2). Mahasiswa membuat rencana palaksanaan kegiatan dengan bimbingan guru pamong dan dosen pembimbing di lapangan.

3). Mahasiswa melakukan praktik layanan informasi maupun publikasi sebanyak 1 kali dalam seminggu, yaitu untuk publikasi sendiri dengan dampingan guru pamong maupun pembimbing selama di lapangan.

4). Mahasiswa melakukan refleksi dari guru pamong memberikan masukan kepada praktikum setelah selesai kegiatan publikasi maupun layanan informasi.

2. Kegiatan PPL

Kegiatan PPL meliputi tiga hal, yaitu:

a. Praktik terbimbing

Praktik kegiatan terbimbing dilakasanakan setelah mahasiswa melakukan pengamatan dan penyusunan program, guru pamong memberikan bimbingan tahap demi tahap, mulai proses konsultasi, penyusunan rencana pelaksanaan pembelajaran, persiapan hingga pelaksanaan praktik mandiri. Masing-masing mahasiswa melaksanakan 3 kali praktik kegiatan terbimbing.

b. Praktik mandiri

Praktik mandiri dilaksanakan secara mandiri (individual) tanpa bimbingan dari para pembimbing di lapangan, mulai dari persiapan sanpai dengan pelaksanaan. Kegiatan mandiri yang dimaksud disini ialah praktik seputar layanan informasi maupun pada bagian publikasi selama masa Praktik Pengalaman Lapangan (PPL) berlangsung. Praktik mandiri ini juga bertujuan untuk melatih kemampuan mahasiswa dalam mengorganisasikan aktivitas maupun kegiatan pembelajaran di lapangan.

c. Ujian praktik mandiri

Ujian praktik ini dilaksanakan diakhir pelaksanaan praktik pengalaman lapangan dengan tujuan untuk melihat sejauh mana peningkatan yang telah dicapai oleh mahasiswa dalam hal ketrampilan maupun hal yang 
berkaitan dengan suatu pekerjaan ditempat tersebut selama kegiatan PPL berlangsung.

\section{Penyusunan Laporan}

Penyusunan laporan merupakan tugas akhir dari kegiatan PPL. Laporan ini berfungsi sebagai pertanggung jawaban mahasiswa atas pelaksanaan PPL. Laporan ini juga merupakan syarat kelulusan. Laporan PPL mencakup seluruh kegiatan PPL mulai dari pembekalan, observasi, praktik terbimbing, praktik mandiri, dan uji praktik kegiatan PPL (pengumpulan tugas selama kegiatan berlangsung). Laporan PPL merupakan laporan individu yang berisi paparan singkat mengenai kegiatan yang telah dilakukan oleh mahasiswa dengan menambahkan refleksi mahasiswa atau kegiatan untuk syarat kelulusan nantinya.

\section{Metode Penggalian Data}

Metode penggalian data disini menggunakan rekapitulasi pengunjung pada website PPID yang mana 104 jumlah pengunjung PPID, sedangakan untuk pengjung portal sendiri mencapai 6,640 per bulan Februari 2021. Dengan catatan banyaknya pengunjung portal lebih tinggi dibandingkan PPID itu sendiri.

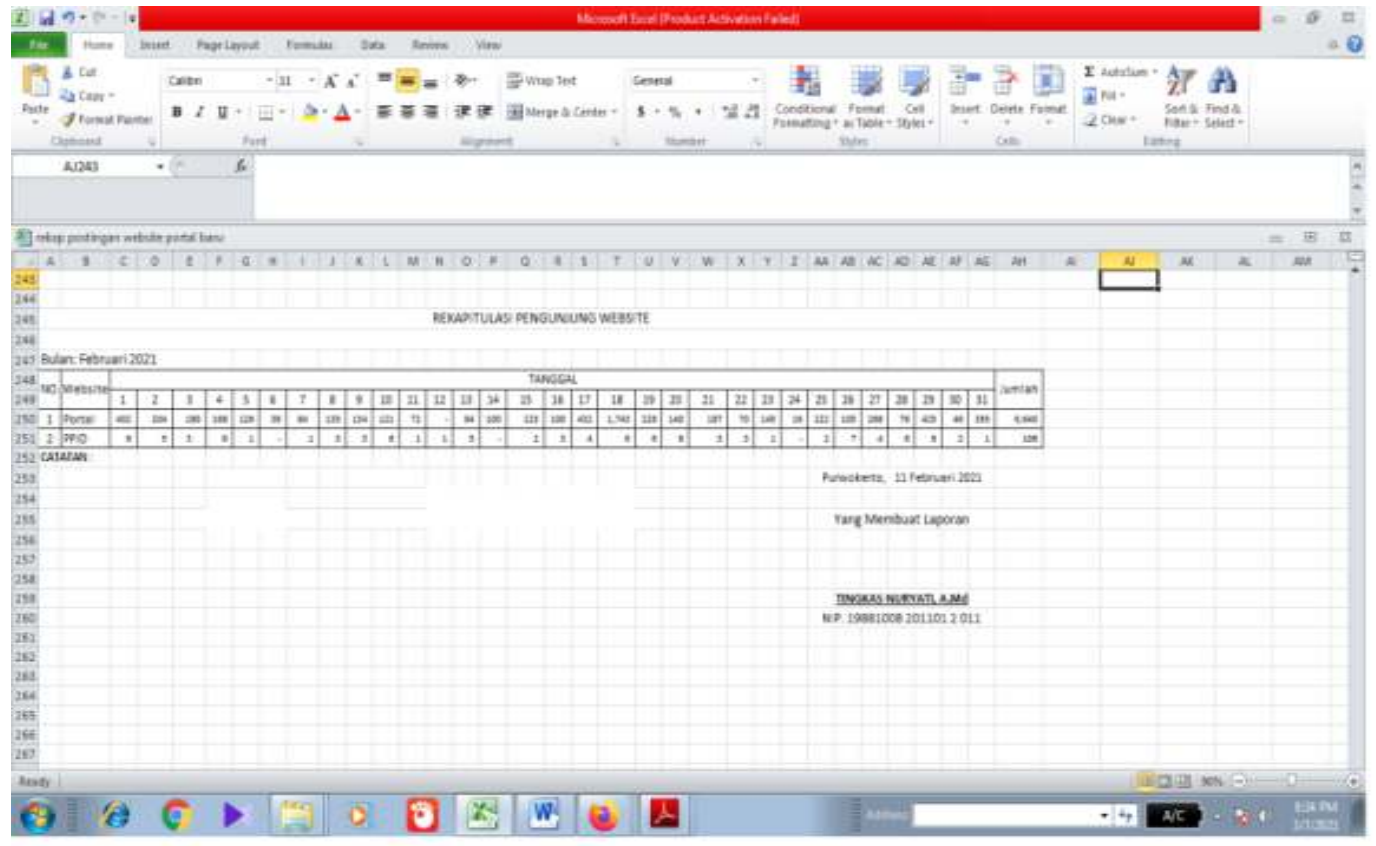




\section{Profil Informan}

Informan dalam riset ini diseleksi secara Porposive yakni memakai metode penentuan ilustrasi dengan seluruh pertimbangan tertentu, metode ini bisa dimaksud selaku sesuatu proses pengambilan ilustrasi dengan memastikan terlebih dulu jumlah ilustrasi yang hendak diambil, kemudian setelah itu pemilihan ilustrasi dicoba bersumber pada tujuan- tujuan tertentu, asalkan tidak menyimpang dari identitas ilustrasi yang sudah diresmikan tadinya. Ada pula metode sampling ini digunakan pada riset yang lebih mengutamakan pada tujuan riset dari pada watak populasinya dalam mencantumkan ilustrasi riset. Walaupun demikian, buat memakai metode ini periset sepatutnya seseorang ahli terhadap ciri populasi. Bersumber pada pengetahuan terhadap populasi itu, hingga unit populasi yang dikira" kunci” diambil selaku ilustrasi penelitiannya. Kemudian yang jadi informan periset yakni selaku berikut:

a. Infoman Kunci (Key Informan) yang merupakan para ahli yang memahami serta memberikan penjelasan berbagai hal yang berkaitan dengan penelitian. ${ }^{5}$ Informan Kunci dalam penelitian ini ialah Kabid Pengelola Informasi.

b. Informan pembimbing merupakan siapa saja yang ditemukan diwilayah penelitian yang memberikan suatu informasi terhadap masalah yang sedang diteliti. Informan pendukung yang terdapat dalam penilitian ini ialah orang yang terlibat secara langsung dalam Aktivitas Dinkominfo tersebut yaitu Ibu Agustina Kusuwa Wardhani serta Ibu Tingkas Nurry.

6. Kerangka Analisis

Miles dan Huberman menggambarkan proses analisis data penelitian kualitatif sebagai berikut:

5 Ardianto Elvinaro, Metode Penelitian untuk Publik Relations, (Bandung: Simbiosa Rekatama Media, 2010), 62. 


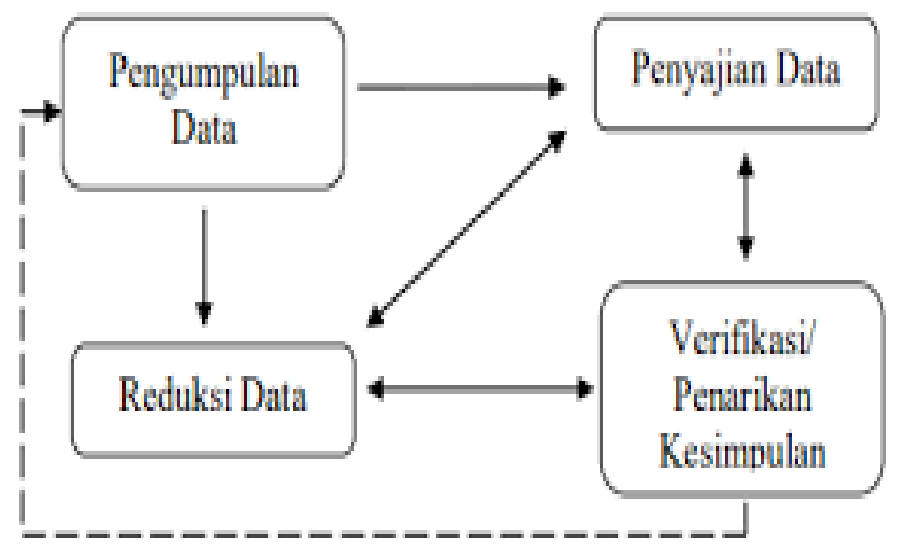

Gambar tersebut memperlihatkan sifat interaktif pada pengumpulan data dengan analisis data. Pengumpulan data merupakan bagian integral dari kegiatan analisis data. Redukdi data adalah upaya menyimpulkan datanya, kemudian memilah-milah data dalam satuan konsep tertentu, kategori tertentu dengan tema tertentu.

Hasil reduksi data nantinya diolah sedemikian rupa supaya terlihat bagiannya secara utuh. Boleh berbentuk sketsa, synopsis, matriks serta bentuk lainnya. Karna prosesnya lebih memudahkan pemaparan dan penegasan serta kesimpulan.

Kerangka analisis disisni adalah penjelasan sementara terhadap suatu gejala yang menjadi objek permasalahan. Kerangka analisis ini disusun berdasarkan pratinjau pustaka dan hasil penelitian yang relevan atau terkait.

\section{HASIL DAN PEMBAHASAN}

\section{HASIL}

Untuk mendapatkan suatu informasi dari komunikasi publik terutama kegiatan yang kaitannya dengan pemrosesan data/informasi publik, untuk melaksanakan tugas tersebut dibebankan kepada bidang PPID yang dijabarkan dalam dua seksi bidang yang ada di Dinas Komunikasi dan Informatika Kab. Banyumas.

Lalu hasil dari penelitian ini nantinya menunjukan bahwa lembaga informatika dan komunikasi di setiap daerah berbeda baik dari nama dan tingkat 
jenjang struktur, akan tetapi tetap proaktif untuk menghimpun suatu informasi publik terkhusus pada bagian yang diproduksi oleh pemerintah daerah. Seperti peraturan daerah, kebijakan pemerintah daerah, perizinan, serta distribusi yang menjadi sangat penting untuk dihimpun karna informasi tersebut sangat penting untuk pengembangan dan kemajuan daerah.

Secara umum pekerjaan di Dinas Komunikasi dan Informatika ialah penulis hanya diminta untuk membantu memasukan data pengunjung website khusunya pada website PPID dengan menggunakan program Ms. Excel, membantu dalam membuat saran pada Web seperti membuat kritik \& saran. Selain itu penulis juga diminta untuk merekap surat keluar masuk yang pada layanan informasi publik.

Pekerjaan lainnya penulis diminta untuk mem-backup hasil pengunjung Portal maupun Website serta memasukkan surat masuk serta mencetak disposisi. Penulis juga belajar untuk membuat nomor agenda surat masuk dan keluar, yang bertujuan untuk memudahkan pencarian surat dan surat tidak akan hilang. Selain diarsipkan secara manual pada sebuah buku agenda surat, surat ini juga diarsiokan pada sistem.

Didalam tahapan ini periset menjabarkan sesuatu hasil dari riset yang di bisa dari hasil wawancara terhadap informan. Setelah itu analisa yang dicoba dari acuan terhadap pengumpulan informasi cocok penanda. Kegiatan Pengelola Data Layanan Publik Berbasis Web pada Dinas Komunikasi serta Informatika Kabupaten Banyumas ini lewat 4 tahapan: pengumpulan data, pengelompokan data, pendokumentasian data dan pelayan publik itu sendiri.

Berdialog kaitannya dengan pengelola data, Dinkominfo ini berfungsi lumayan berarti dalam melaksanakan sesuatu tugas dan guna humasnya yang betujuan buat pelayanan/ penyebaran data terhadap warga. Dalam suatu lembaga baik pemerintah ataupun swasta humas ini mempunyai kedudukan serta guna berarti dalam seluruh kegiatan yang dicoba di sesuatu lembaga tersebut.

Kegiatan yang dicoba oleh Dinkominfo kaitannya dengan aktivitas pengelola data layanan publik baik lewat media, maupun dengan fasilitas prasarana yang lain yakni dengan iktikad buat menggapai sesuatu tujuan penyebaran data terhadap warga, penyajian informasi bersumber pada dengan proses dari guna Dinkominfo dalam pengelolaan data layanan publik. 
Sejak penulis menjalankan aktifitas magang yang dilalui penulis sepanjang satu bulan. Secara totalitas penulis lebih banyak ditugaskan didalam pelayanan data aktivitas Dinas serta kegiatan wilayah yang terjalin di Kabupaten Banyumas. Penulis menemukan pengalaman baru dalam perihal membuat narasi, baik siaran ataupun yang lain. Membuat ILM (Iklan Layanan Mayarakat), mengambil informasi kabar dari suatu project peliputan. Tidak hanya itu pula penulis menemukan pengalaman gimana bekerja di Kantor Pemerintahan. Seperti itu sekilas pekerjaan yang dicoba oleh penulis sepanjang kurang lebih 40 hari di Dinas Komunikasi serta Informatika Kabupaten Banyumas.

Setelah penulis melaksanakan sesuatu tinjauan langsung dan memperoleh data serta informasi kaitannya dengan riset ini, setelah itu periset melaksanakan sesuatu analisa terhadap pengelola data yang dicoba pada kantor Dinas Komunikasi serta Informatika Kabupaten Banyumas buat menciptakan kesesuain pada konsep teorinya. Dari hasil riset ini, periset merumuskan kalau pengelolaan data layanan publik berbasis web di Dinkominfo Kab. Banyumas telah melakukakan tahapan yang lumayan baik. Dalam pengelola informasi layanan publik dalam pelayanan informasi berbasis website yang cukup akurat, Dinkominfo juga perlu adanya melakukan pengelolaan informasi dengan baik, konsisten serta juga bertanggung jawab melalui kegiatan yang meliputi: pengumpulan, pengelompokkan, pendokumentasian informasi serta pelayanan informasi. Adapun penjelasannya sebagai berikut:

\section{a. Pengumpulan Informasi}

Di dalam sebuah Kegiatan yang sangat penting peranannya dalam melakukan suatu pengelolaan informasi serta dokumentasi. Pengumpulan informasi ini bisa berupa aktivitas penghimpunan kegiatan yang telah, sedang dan atau akan dilaksanakan oleh setiap satuan kerja. Kegiatan penghimpunan informasi ini dari setiap satuan organisasi/ unit organisasi untuk mendukung agar terlaksananya suatu penyelenggaraan pelayanan informasi. Lalu kemudian, setiap satuan organisasi atau unit organisasi itu perlu adanya kegiatan yang memperhatikan sejumlah hal yang terkait penyelenggaraan kegiatan pengumpulan informasi tersebut.

Dalam menjalankan satu tugas pokok serta fungsinya, satuan kerja Dinas Komunikasi dan Infomatika Kabupaten Banyumas perlu memiliki adanya 
kemampuan dalam mengumpulkan informasi sebagai bahan acuan untuk diolah serta dipulikasikan pada masyarakat. Dengan kemampuan mengumpulkan informasi ini, satuan kerja juga perlu memiliki kualitas dalam pengumpulan informasi. Contohnya seperti informasi itu bersifat aktual, faktual, dan terpercaya. Selanjutnya, kegiatan pengumpulan informasi ini, para satuan kerja Dinas Komunikasi dan Informatika harus menciptakan saling pengertian, dukungan, kerja sama serta toleransi antara sesama. Karena hal ini bisa memberikan semangat positif dan akan mendapatkan hasil yang baik juga untuk dipublikasikan.

b. Pengklasifikasian Informasi

Pengelompokan informasi atau bisa disebut juga dengan pengklasifikasian informasi sering kali dalam suatu organisasi melakukan pengklasifikasian informasi dikarnakan pelaksanaan ini sudah menjadi kebijakan sebuah organisasi. Dalam melakukan tahapan ini banyak keuntungan yang nantinya akan diperoleh, seperti: baik dari ketersediaan suatu informasi, pengamanan informasinya, hingga dapat meningkatkan aspek kerahasiaan suatu informasi, serta meningkatkan keutuhan isi informasi. Pada tahapan ini dianggap sangatlah penting karna dapat memberikan pengamanan sumber daya organisasi serta dapat membuat pengelola informasi menjadi lebih efisien serta efektif. Lalu kemudian dengan ini semua maka feedback yang didapat juga akan membantu meningkatkan baik kualitas data atau informasi yang nantinya digunakan sebagai bahan untuk mengambil suatu keputusan.

Didalam kegiatan mempublikasikan informasi atau berita yang kaitannya dengan Kabupaten Banyumas, Dinas Komunikasi dan Informatika dapat menggunakan media elektronik seperti: Videotron, media cetak atau media sosial bahkan skill multimedia dapat juga dimunculkan disini misal untuk membuat desain grafis atau video cinematic yang kaitannya dengan informasi yang ditayangkan lewat video ataupun lainnya. Untuk memberikan informasi yang akurat, tepat serta terpercaya Dinas Komunikasi dan Informatika bekerja sama dengan satuan dinas lainnya yang berkaitan dengan sistem pemerintahan. Kaitannya disini mengacu pada humas pemerintah dengan pengedukasian informasi terhadap masyarakat yang bertujuan untuk menginformasi, mengawasi, mendidik, menghibur serta membangkitkan kesadaran masyarakat akan pentingnya 
untuk menjaga potensi yang ada diwilayah sendiri khususnya di Kabupaten Banyumas.

\section{c. Pelayanan Informasi}

Pelayanan informasi disini merupakan tahapan terakhir setelah melakukan pengumpulan baik data maupun informasi, yang mana pada pelayanan informasi ini sebuah bidang organisasi akan menyampaikan atau mempublish info kepada khayalak masyarakat.

Dari hasil penelitian penulis terhadap objek yang diteliti, dapat dikatakan kegiatan pelayanan informasi di Dinkominfo Kab. Banyumas tidak hanya sekedar memberi ataupun menyebarluaskan suatu infomasi, akan tetapi memiliki sistem mekanismenya sendiri. Didalam ini besifat publik yang mana nantinya infomasi ini akan diumumkan melalui berbagai macam media, seperti halnya media cetak bahkan sampai ke media online. Adapun yang dikecualikan ialah informasi yang kaitannya dengan surat menyurat yang seharusnya memang tidak untuk dipublikasikan kepada khalayak bebas.

Dapat disimpulkan bahwasannya dalam pelayanan informasi yang telah diberikan oleh suatu badan publik Dinas Komunikasi dan Informatika Kabupaten Banyumas yaitu, terbuka atau transparan yang mana merupakan pelayanan ini membutuhkan informasi yang bersifat terbuka serta cepat dan akurat. Cepat disini maksdunya dalam hal akses terbuka, ialah dapat diakses dimana oleh semua pihak yang memang membutuhkan suatu informasi tersebut.

\section{d. Pendokumentasian Inforrmasi}

Suatu kegiatan yang sangat tidak dapat dipisahkan dalam pengelolaan Informasi, dimana pada tahap ini merupakan kegiatan pencatatan serta penyimpanan dari semua data dan informasi yang diperoleh dari satuan kerja, dengan demikan informasi akan tersusun dan memudahkan pula untuk mengelolanya nanti.

Pendokumentasian informasi merupakan kegiatan penyimpanan data dan informasi, catatan atau keterangan yang dibuat nantinya diterima oleh satuan kerja 
di lingkungan Kementerian Komunikasi dan Informatika dalam rangka membantu PPID dalam melayani permintaan informasi. ${ }^{6}$

\section{PEMBAHASAN}

Dalam tahapan ini berisi data yang sudah disajikan pada hasil penelitian, lamgkah selanjutnya penulis menganalisis data yang berkaitan dengan perumusan pada bagian pertama yang mana isinya yaitu, bagaimana pengelolaan informasi layanan publik di Dinkominfo Kab. Banyumas. Sebagaimana yang telah dipaparkan penulis di bab sebelumnya analisa penulis menggunakan metode analisis deskriptif kualitatif, yaitu analisa yang menggunakan kalimat-kalimat.

Dari hasil penelitian, peneliti mengemukakan bahwa pengelola informasi layanan publik yang terdapat di Dinas Komunikasi dan Informatika Kabupaten Banyumas telah melakukan tahapan yang cukup baik. Dalam pengelola informasi ini telah memberikan informasi yang akurat maka Dinkominfo perlu melakukan pengelolaan informasi secara baik, konsisten serta bertanggung jawab melalui beberapa kegiatan yang meliputi pengumpulan, pendokumentasian, pengelompokkan informasi serta pelayanan informasi yang lainnya.

\section{a. Pengumpulan Informasi}

Pengumpulan informasi disini berupa suatu kegiatan yang sangat di pentingkan dalam pengelolaan informasi maupun dokumentasi. Pengumpulan informasi ini berupa suatu aktivitas penghimpunan kegiatan yang telah atau sedang dan akan dilaksanakan oleh setiap satuan kerja. kegiatan penghimpunan informasi dari setiap satuan organisasi atau unit organisasi untuk mendukung penyelenggaraan pelayanan informasi. Setiap satuan organisasi ataupun unit organisasi perlu memperhatikan sejumlah hal yang terkait penyelenggaraan kegiatan pengumpulan informasi tersebut.

Kegiatan pengumpulan informasi ini, satuan kerja Dinas Komunikasi dan Informatika Kabupaten Banyumas harus menciptakan saling pengertian, dukungan,

${ }^{6}$ Komisi Informasi Pusat RI. Peraturan Komisi Informasi No. 1 tahun 2017 tentang Pengklasifikasian Informasi Publik. Online at https://komisiinformasi.go.id/?portfolio=peraturankomisi-informasi-nomor-1-tahun-2017. Di akses pada tanggal 15 April 2021 Pukul 10:00. 
kerja sama serta toleransi antara sesama. Karna hal ini bisa memberikan semangat positif dan akan mendapatkan hasil yang baik juga untuk dipublikasikan kepada khayalak publik.

\section{b. Pelayanan Informasi}

Dalam kegiatan pelayanan informasi yang telah disediakan dan nantinya akan diumumkan secara berkala setiap saat. Maksudnya disini dalam secara berkala itu informasi publik yang sudah disediakan terus dilayani melalui website oleh Dinas komunikasi dan Informatika Kabupaten Banyumas dan juga melalui media cetak. Kemudian untuk informasi yang disediakan setiap saat itu maksudnya semua infomasi publik dikategorikan tersedia setiap saat tetap yang sudah sediakan oleh Dinas Komunikasi dan Informatika Kabupaten Banyumas.

Pelayan informasi merupakan sebuah bentuk kegiatan yang memastikan bahwa informasi serta pengetahuan tersedia ketika dibutuhkan yang digunakan sebagai pembuat keputusan dengan mengalokasikan sumber yang tersedia. ${ }^{7}$

\section{c. Pendokumentasian Informasi}

Dalam tahap pendokumentasian ini semua informasi baik yang sudah dipublikasikan nantinya juga akan disimpan dalam dokumen serta komputerisasi. Tugas serta fungsi satuan kerja dalam memberikan bukti fisik kepada pemerintah yang akan berguna untuk masa mendatang. Dokumentasi ini merupakan pekerjaan mengumpulkan, menyusun dan mengelola dokumen tertulis (literature) yang mencatat semua aktivitas manusia. Dianggap berguna untuk dijadikan bahan keterangan dan penerangan berbagai soal. ${ }^{8}$

\section{KESIMPULAN}

Kegiatan Pengumpulan informasi satuan Dinkominfo Kab. Banyumas memiliki kemampuan dalam mencari berita yang akurat, aktual, faktual, terpercaya serta berkompeten sesuai dengan tugas pokok dan fungsnya. Mengklasifikasikan informasi juga meliputi: informasi yang wajib disediakan dan diumumkan secara berkala, informasi publik yang diumumkan secara merata, informasi publik yang

\footnotetext{
${ }^{7} \mathrm{http}: / /$ www.bkpm go id- ppid mekanisme pelanan informasi. Diakses pada tanggal 10 Maret 2021 pukul 12:29

${ }^{8}$ Basuki, Sulistyo, Dasar-dasar Dokumentasi, (Jakarta: Universitas Terbuka), 10.
} 
wajib tersedia tiap saat. Pelayanan informasi ini merupakan bentuk kegiatan yang memastikan bahwa informasi dan pengetahuan tersedia ketika dibutuhkan. Indikator dalam mencapai keberhasilan layanan informasi publik yaitu pada pelayanan informasi yang secara transparan, akuntabel dan terdapat kesamaan hak. Dalam pendokumentasian, mendeskripsi informasi, memverifikasi informasi, otentikasi informasi, pemberian kode informasi, penataan informasi dan penyimpanan informasi sudah cukup bagus dan tertata.

Untuk sarannya sendiri diharapkan Dinas Komunikasi dan Informatika Kabupaten Banyumas meskipun sudah menyajikan dan menyediakan informasi yang akurat, aktual, faktual tepat, dan terpercaya. mungkin untuk kedepannya lebih diperbaiki serta dipertahankan dari apa yang sekarang sudah di miliki. Serta Dinas Komunikasi dan Informatika Kabupaten Banyumas harus mensosialisasikan program kegiatan pada publik serta media yang digunakan untuk mempublikasikan informasi, agar publik tidak ketinggalan informasi dan selalu update terkait informasi masa kini.

\section{DAFTAR PUSTAKA}

Basuki, Sulistyo, Dasar-dasar Dokumentasi, Jakarta: Universitas Terbuka,

Bungin, Burhan. Metode Penelitian Kualitatif, Jakarta: Kencana Prenada Media Group, 2005.

BKPM. Mekanisme Pelayanan Informasi, On line at https://www.bkpm.go.id/id/ppid/mekanisme-pelayanan-informasi. Diakses pada tanggal 10 Maret 2021 pukul 12:29

Elvinaro, Ardianto. Metode Penelitian untuk Publik Relations, Bandung: Simbiosa Rekatama Media, 2010.

EPPID. https://eppid.kominfo.go.id/. Diakses Sabtu, 6 Maret 2021 pukul 12:35.

Komisi Informasi Pusat RI. Peraturan Komisi Informasi No. 1 tahun 2017 tentang Pengklasifikasian Informasi Publik. Online at https://komisiinformasi.go.id/?portfolio=peraturan-komisi-informasinomor-1-tahun-2017. Di akses pada tanggal 15 April 2021 Pukul 10:00.

Moleong, Lexy J. Metode Penelitian Kualitatif. Bandung: Remaja Rosdakarya, 2009.

PPID Kabupaten Banyumas. Profil Singkat PPID. Online at http://ppid.banyumaskab.go.id/page/21788/profil-singkat-ppid. Di akses pada tanggal 6 Maret 2021 Pukul 13:05 
Siregar, Amir Effendi. Mengawal Demokratisasi Media, Menolak Konsentrasi Membangun Keberagaman, Jakarta: TIFA, 2014.

Sugiono, Metode Penelitian Kuantitatif, Bandung: Alfabeta, 2009.

Sugeng, Winarno., dan Indah Septieem Mery, Analisis Jaringan Komputer Dinas Komunikasi dan Informatika, dalam Jurnal Informatika Vol. 3, JanuariApril 2012. 
Mirra Saefunnissa, Aktifitas Pengelolaan Layanan Publik Berbasis Website di Dinas Komunikasi dan Informatika Banyumas $\mid 122$ 